\title{
Morphometric Relationships of Nemipterus randalli (Russell, 1986) from İskenderun Bay
}

\author{
Ramazan YAZICI $^{1^{*}}$ Okan YAZICIOĞLU ${ }^{2} \quad$ Tamer AKKAN $^{3}$ \\ ${ }^{1 *}$ Laborant and Veterinary Health Program, Veterinary Department, Çiçekdağgl Vocational School, Kirşehir Ahi Evran University, Kirş̧ehir, Turkey \\ ${ }^{2}$ Department of Plant and Animal Production, Vocational School of Technical Sciences, Kirșehir Ahi Evran University, Kirșehir, Turkey \\ ${ }^{3}$ Giresun University, Science and Art Faculty, Biology Department, Giresun, Turkey
}

How to cite: Yazıcı, R., Yazıcıoğlu, O. \& Akkan, T. (2020). Morphometric Relationships of Nemipterus randalli (Russell, 1986) from İskenderun Bay. J. Anatolian Env. and Anim. Sciences, 5(4), 772-776.

Atıf yapmak için: Yazıcı, R., Yazıcıoğlu, O. \& Akkan, T. (2020). İskenderun Körfezi’ndeki Nemipterus randalli (Russell, 1986)'nin Morfometrik İlişkileri Anadolu Çev. ve Hay. Dergisi, 5(4), 772-776.

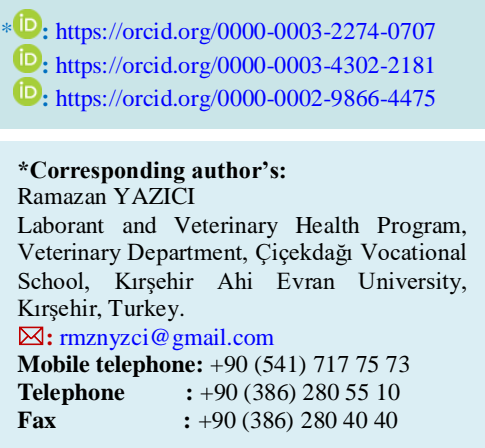

Abstract: In this study was aimed to describe the relationships between morphometric characters and total length of Nemipterus randalli. A total of 107 samples were collected from Iskenderun Bay in November 2018. The results show that estimates of total length of this species through morphometric character are reliable. Linear regressions showed the best accuracy for all relationships between morphometric characters and total length. Among obtained relationships, the best fit was recorded between total length and head length, while the lowest value of coefficient of determination was also determined between total length and horizontal mouth gape. Establishing morphometric relationships can provide an alternative to back-calculation of fish length and can provide information that aids in understanding complex relationships between predator and prey size. The equations generated to obtain the total length of the fish using morphometric character data can be used in dietary studies of top predators and paleontological studies.

Keywords: İskenderun Bay, Linear Relationships, Morphometry, Nemipterus randalli.

\section{İskenderun Körfezi’ndeki Nemipterus randalli (Russell, 1986)’nin Morfometrik İlişkileri}

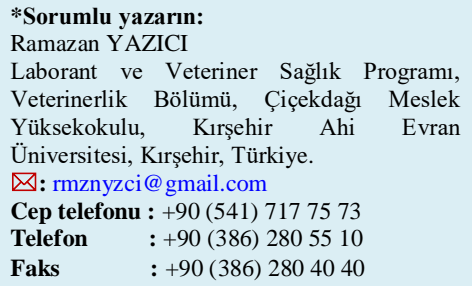

\begin{abstract}
Öz: Bu çalışmada, Nemipterus randalli'nin morfometrik karakterler ile toplam uzunluğu arasındaki ilişkileri tanımlamak amaçlanmıştır. Kasım 2018 tarihinde toplam 107 örnek İskenderun Körfezi'nden elde edilmiştir. Sonuçlar, morfometrik karakter üzerinden bu türün toplam uzunluğunun tahminlerinin güvenilir olduğunu göstermektedir. Doğrusal regresyonlar, morfometrik karakterler ve toplam uzunluk arasındaki tüm ilişkiler için en iyi doğruluğu göstermiştir. Elde edilen ilişkiler arasında en iyi uyum toplam uzunluk ve baş uzunluğu arasında kaydedilmiş iken, en düşük korelasyon katsayısı değeri ise toplam uzunluk ile yatay ağız açıklığ 1 arasında belirlenmiştir. Morfometrik ilişkilerin kurulması, balık uzunluğunun geriye doğru hesaplanmasına bir alternatif sağlayabilir ve avcı ile av boyutu arasındaki karmaşı ilişkilerin anlaşılmasına yardımcı olan bilgiler sağlayabilir. Morfometrik karakter verilerini kullanarak balıkların toplam uzunluğunu elde etmek için oluşturulan denklemler, predator balıkların beslenme çalışmalarında ve paleontolojik çalışmalarda kullanılabilir.
\end{abstract}

Anahtar kelimeler: İskenderun Körfezi, Linear ilișkiler, Morfometri, Nemipterus randalli.

\section{INTRODUCTION}

Nemipterus randalli Russell, 1986, Randall's threadfin bream, has a common distribution western Indian Ocean including the east and west coasts of India, Pakistan, the Persian (Arabian) Gulf, Red Sea, including the Gulf of
Aqaba, the Gulf of Aden, and the eastern African coast: the Seychelles and Madagascar (Russell, 1990). Randall's threadfin bream being benthic species, lives on sand or mud bottoms in depths of 22 to $225 \mathrm{~m}$ (Russell, 1990).

The morphometric characters of fishes are a good tool for estimating about feeding style, the life history, and 
swimming abilities of fish (Kováč et al., 1999). The calculated analyses from morphometric character help to understand the relationships between the body parts. Morphometric characters can identify aspects of body shape in fishes. These characters can commonly use in fisheries biology to measure discreteness between different fish stocks (Qadri et al., 2017) and relationships among various taxonomic categories (Turan, 1999).

There are researches on feeding habits (Gurlek et al., 2010), age and growth (Erguden et al., 2010; Innal et al., 2015; Demirci et al., 2020), length-weight relationships (Erguden et al., 2009), fish length and otolith size relationships (Uyan et al., 2019) and reproductive feature (Demirci et al., 2018) of Randall's threadfin bream. The available data on the morphometric characteristics of Randall's threadfin bream are very rare. Only Innal et al. (2015) published some comparable morphometric data on this species from Antalya Gulf. Moreover, the study about morphometric relations was not found for İskenderun Bay populations. The aim of paper is to determine relationships between morphometric characters and total length.

\section{MATERIAL AND METHOD}

Samples were collected from İskenderun Bay in November 2018. Sampling operations were carried out with a medium water trawl net made of polyethylene (PE) material $(\varnothing 0.40 * 10)$ with a mouth opening of $1.5-2 \mathrm{~m}, 22$ $\mathrm{mm}$ mesh width, $35 \mathrm{~m}$ length and $7 \mathrm{~m}$ width, of Iskenderun Bay Denizciler area. A total of 107 specimens were analyzed to determine relationships between the morphometric characters and total length. A total of eight morphometric character measurements were made on left side of the body of each fish specimen. The total length (TL) of the fish were measured to the nearest $0.1 \mathrm{~cm}$ using fish measuring board. The measurements of the others morphometric characters were done by using a digital caliper. The sex of samples was detected by the examination of gonads macroscopically. The morphometric features studied included total length (TL), pectoral fin ray length (PFRL), dorsal fin length (DFL), head height $(\mathrm{HH})$, head length $(\mathrm{HL})$, body height $(\mathrm{BH})$, vertical mouth gape (VMG) and horizontal mouth gape (HMG) of the specimens. The morphometric character was measured as given in Table 1.

Linear $(y=a x+b)$ and non-linear $\left(y=a x^{b}\right.$, power model) regression models were calculated to determine what equations best described the relationships between morphometric character and total length. Where $\mathrm{Y}$ is the variable (morphometric character), ' $\mathrm{x}$ ' is the independent character (total length) and ' $a$ ' and ' $b$ ' are constants. The model with the highest coefficient of determination $\left(\mathrm{r}^{2}\right)$ was chosen to describe these relationships.

Table 1. Measured morphometric character of Nemipterus randalli

\begin{tabular}{|c|c|c|}
\hline [orphometric character & Abbreviation & Description of measured parameters \\
\hline Total length & TL & $\begin{array}{l}\text { Measurement of body length from tip of } \\
\text { largest jaw to the largest part of caudal fin }\end{array}$ \\
\hline Pectoral Fin Ray Length & PFRL & $\begin{array}{l}\text { The length of the longest find ray of } \\
\text { pectoral fin. }\end{array}$ \\
\hline Dorsal Fin Length & DFL & $\begin{array}{l}\text { Distance from the start of the fin to the end } \\
\text { by the dorsal side. }\end{array}$ \\
\hline Head Height & $\mathrm{HH}$ & $\begin{array}{l}\text { Distance between the upper and lower } \\
\text { edges of the head in ventral position. }\end{array}$ \\
\hline Head Length & HL & $\begin{array}{l}\text { Distance between the anterior head } \\
\text { extremity and the end of operculum }\end{array}$ \\
\hline Body Height & $\mathrm{BH}$ & Maximum vertical length of body \\
\hline Vertical Mouth Gape & VMG & $\begin{array}{l}\text { Greater distance between the measured lips } \\
\text { with mouth open }\end{array}$ \\
\hline Horizontal Mouth Gape & HMG & $\begin{array}{l}\text { Internal distance from the mouth when fully } \\
\text { open }\end{array}$ \\
\hline
\end{tabular}

The t-test was used to compare the outcomes of morphometric measurements between sexes. Paired t-test was used to determine the difference in measurements of left and right pectoral fin rays length. The differences in the slope of regressions equations between males and females were tested by analysis of covariance (ANCOVA). Statistical analyses were performed with Minitab 17.0 software package and a level of significance of $\alpha=0.05$ was accepted.

\section{RESULTS}

A total of 107 specimens were examined for determining the relationships between morphometric characters and total length. Of the total fish examined, 36 were females and 71 were males. The total lengths of all samples ranged from $11.1 \mathrm{~cm}$ to $19.3 \mathrm{~cm}$, with a mean value of $15.3 \pm 1.518 \mathrm{~cm}(\mathrm{sd})$. The descriptive statistics of morphometric characters are given in Table 2. The mean values of TL, PFRL, DFL HH, HL, and BH of females were higher than mean values of male (Table 2). The mean values of mouth morphometric characters (VMG and HMG) were detected the highest in males (Table 2).

There was significant difference in the measurements of all morphometric character (TL, PFRL, DFL, HH, HL, BH, VMG, and HMG) between females and males ( $\mathrm{t}$-test, $\mathrm{p}<0.0 .5)$. For this reason, the relationships between total length and morphometric characters were generated separately according to female, male, and entire sample. The differences in morphometric measurements of both left and right pectoral fin ray length in female and male are not statistically significant (paired t-test, $\mathrm{p}>0.05$ ). Therefore, the left pectoral fin ray length was used to determine regression model. 
Table 2. The descriptive statistics of morphometric characters of female, male, and entire sample in Nemipterus randalli.

\begin{tabular}{|c|c|c|c|c|c|c|}
\hline Morp. Characters & Sex & $\mathbf{n}$ & Min-Max & Mean & SD & t-test \\
\hline \multirow{3}{*}{$\mathrm{TL}$} & Female & 36 & $11.1-18.5$ & 15.9 & 1.497 & \multirow{3}{*}{$\mathrm{P}<0.05$} \\
\hline & Male & 71 & $12.0-19.3$ & 15.0 & 1.455 & \\
\hline & Entire & 107 & $11.1-19.3$ & 15.3 & 1.518 & \\
\hline \multirow{3}{*}{ PFRL } & Female & 36 & $2.9000-4.8000$ & 4.2083 & 0.4735 & \multirow{3}{*}{$\mathrm{P}<0.05$} \\
\hline & Male & 71 & $2.6000-4.6000$ & 3.5803 & 0.3698 & \\
\hline & Entire & 107 & $2.6000-4.8000$ & 3.7916 & 0.5032 & \\
\hline \multirow{3}{*}{ DFL } & Female & 36 & $4.400-7.300$ & 6.208 & 0.643 & \multirow{3}{*}{$\mathrm{P}<0.05$} \\
\hline & Male & 71 & $4.4000-7.7000$ & 5.8718 & 0.5844 & \\
\hline & Entire & 107 & $4.4000-7.7000$ & 5.9850 & 0.6227 & \\
\hline \multirow{3}{*}{$\mathrm{HH}$} & Female & 36 & $2.1000-4.4000$ & 3.4028 & 0.4672 & \multirow{3}{*}{$\mathrm{P}<0.05$} \\
\hline & Male & 71 & $2.3000-4.2000$ & 3.0085 & 0.4006 & \\
\hline & Entire & 107 & $2.1000-4.4000$ & 3.1411 & 0.4672 & \\
\hline \multirow{3}{*}{$\mathrm{HL}$} & Female & 36 & $2.9000-5.0000$ & 4.1389 & 0.4416 & \multirow{3}{*}{$\mathrm{P}<0.05$} \\
\hline & Male & 71 & $2.8000-5.0000$ & 3.9113 & 0.4393 & \\
\hline & Entire & 107 & $2.8000-5.0000$ & 3.9879 & 0.4511 & \\
\hline \multirow{3}{*}{$\mathrm{BH}$} & Female & 36 & $2.9000-5.4000$ & 4.3278 & 0.5262 & \multirow{3}{*}{$\mathrm{P}<0.05$} \\
\hline & Male & 71 & $2.6000-5.1000$ & 3.9178 & 0.4876 & \\
\hline & Entire & 107 & $2.6000-5.4000$ & 3.9178 & 0.5784 & \\
\hline \multirow{3}{*}{ VMG } & Female & 36 & $1.0000-2.9000$ & 1.6667 & 0.3825 & \multirow{3}{*}{$\mathrm{P}<0.05$} \\
\hline & Male & 71 & $1.5000-3.4000$ & 1.9099 & 0.2742 & \\
\hline & Entire & 107 & $1.0000-3.4000$ & 1.8280 & 0.3336 & \\
\hline \multirow{3}{*}{ HMG } & Female & 36 & $0.9000-2.8000$ & 1.5306 & 0.3311 & \multirow{3}{*}{$\mathrm{P}<0.05$} \\
\hline & Male & 71 & $1.4000-3.2000$ & 1.8845 & 0.2901 & \\
\hline & Entire & 107 & $0.9000-3.2000$ & 1.7654 & 0.3464 & \\
\hline
\end{tabular}

Both linear and non-linear regression model were calculated to determine the relationships between morphometric characters. The linear regression model was showed the best fitted compared to the non-linear regression for expressing these relationships. All morphometric measurements were positively related to fish total length, with $r^{2}$ values ranging between 0.22 and 0.87 . No significant difference was observed in slopes (b) of relationships between morphometric characters of females and males (ANCOVA, p>0.05). However, slopes (b) of TL-VMG and TL-HMG relationships were statistically different between female and male (ANCOVA, p<0.05).

The all morphometric characters were showed well correlated with the total length, except the mouth morphometric characters. Among calculated these relationships, the highest value of the coefficient of regression $\left(\mathrm{r}^{2}\right)$ was obtained for total length (TL) and head length (HL) in entire sample, while the lowest value of coefficient of determination was detected between total length (TL) and horizontal mouth gape (HMG). The $\mathrm{r}^{2}$ values of TL-HL, TL-HH, TL-PFRL, and TL-BH relationship were higher in male, while the $\mathrm{r}^{2}$ values of TLDF, TL-HMG, and TL-VMG relationship were the higher in female (Figure 1 and Figure 2).

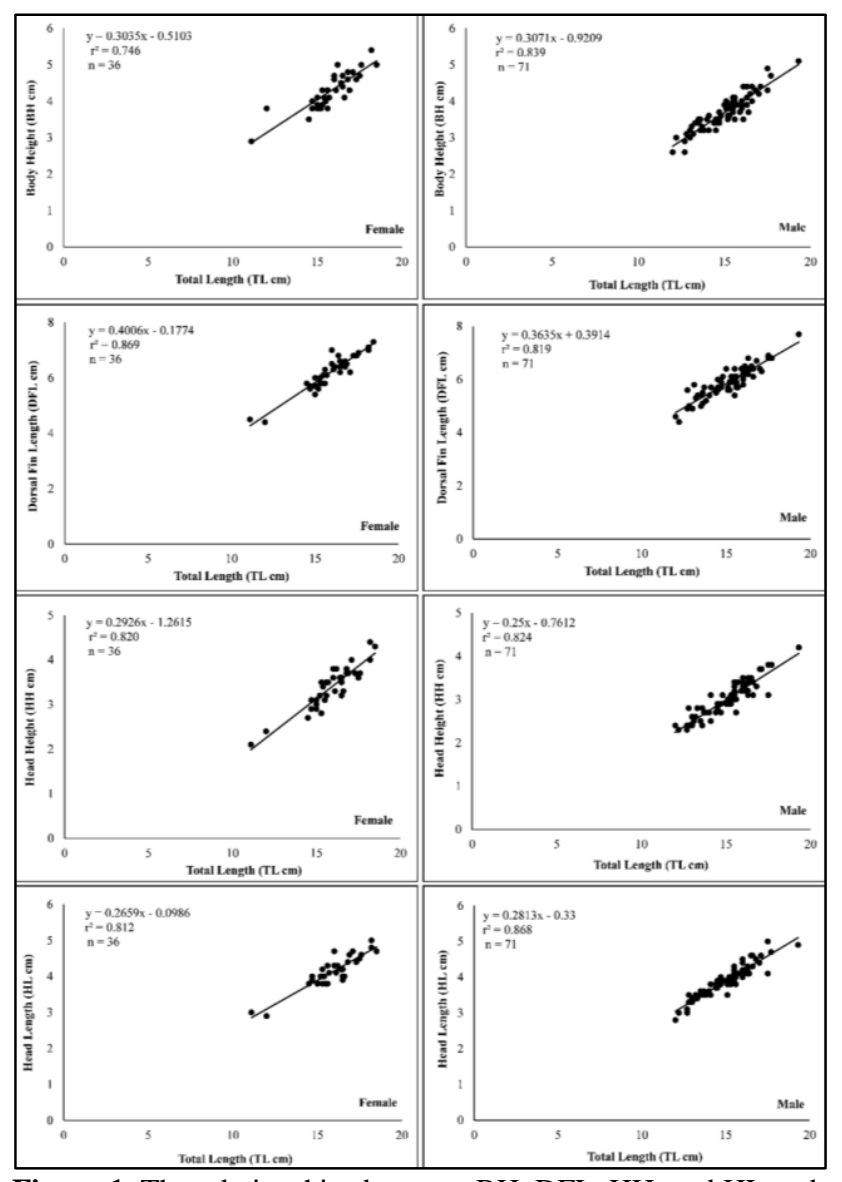

Figure 1. The relationships between BH, DFL, HH, and HL and and total length in females and males of Nemipterus randalli. 


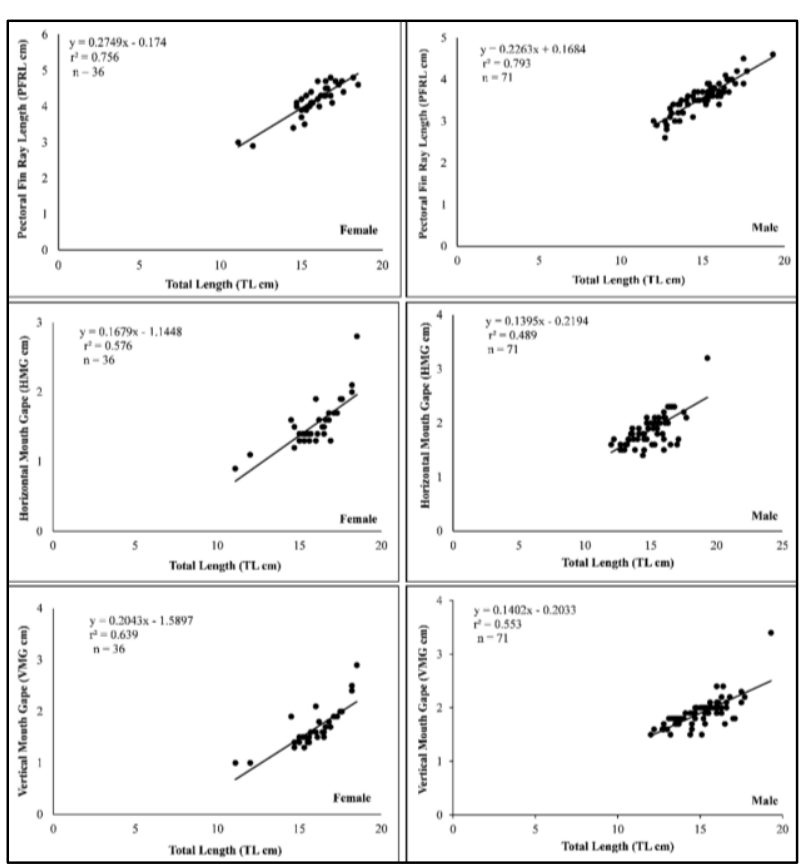

Figure 2. The relationships between PFRL, HMG, and VMG and total length in females and males of Nemipterus randalli.

\section{DISCUSSION AND CONCLUSION}

The biological features such as age and growth, length-weight relationships, fish length and otolith size relationship, and reproduction feature of N.randalli Antalya Gulf and İskenderun Bay population were determined by different researchers (Erguden et al., 2009; Erguden et al., 2010; Özvarol, 2014; Uyan et al., 2019; Demirci et al., 2020). Little information is available on the morphometric character measurements of $N$. randalli (Innal et al., 2015). Since there is no study on relationships between morphometric measures and body length for Randall's threadfin bream inhabiting İskenderun Bay, the comparisons were done the other populations of this species

The linear regression model is generally chosen to detect relationships between morphometric characters and length of the fish (Šantić et al., 2011). In this study, both linear and non-linear models were analyzed for defining the relationships between morphometric characters and total length. The simple linear regression model determined morphometric relationships, for the eight morphometric features evaluated here had higher correlation coefficients than non-linear model. Similarly, studies that being high positive correlation coefficients of morphometric relationships have been reported (Innal et al., 2015; Balai et al., 2017).

The mean values of morphometric measurements of females were higher than mean values of male in this study. These differences between morphometric characters for sexes in this study are in general agreement with other studies reported on Amblypharyngodon mola (Gogoi \& Goswami, 2015). However, Innal et al. (2015) stated that length and weight of males were higher than females in $N$ randalli.

The morphometric characters of Randall's threadfin bream were all positively related to fish total length. The lowest determination coefficient value was found between the mouth measurements and total length in this study. The relationships between other characters and total length had high determination coefficient values.

In conclusion, the use of all measurements except mouth measurements is more reliable for assessing and calculating morphometric data. There is a significant difference in size and body depth between both the sexes.

\section{REFERENCES}

Balai, V.K., Sharma, L.L. \& Ujjania, N.C. (2017). Morphometric relationship of Indian major carps (Catla catla, Labeo rohita and Cirrhinus mrigala) form Jaisamand Lake, Udaipur (India). Journal of Entomology and Zoology Studies, 5(3), 547-550.

Demirci, S., Demirci, A. \& Şimşek, E. (2018). Spawning season and size at maturity of a migrated fish, Randall's Threadfin Bream (Nemipterus randalli) in Iskenderun Bay, Northeastern Mediterranean, Turkey. Fresenius Environmental Bulletin, 27, 503-507.

Demirci, S., Demirci, A. \& Şimşek, E. (2020). The Validation of Different Growth Models of Randall's Threadfin Bream, Nemipterus randalli (Russell, 1986), in Northeastern Mediterranean Sea. Pakistan Journal of Zoology, 52(3), 11131119 .

DOI:

10.17582/journal.pjz/20180327130349

Erguden, D., Turan, C. \& Gurlek, M. (2009). Weightlength relationships for 20 Lessepsian fish species caught by bottom trawl on the coast of Iskenderun Bay (NE Mediterranean Sea, Turkey). Journal of Applied Ichthyology, 25(1), 133-135. DOI: 10.1111/j.1439-0426.2008.01198.x

Erguden, D., Turan, C., Gurlek, M., Yaglioglu, D. \& Gungor, M. (2010). Age and growth of the Randall's threadfin bream Nemipterus randalli (Russell, 1986), a recent Lessepsian migrant in Iskenderun Bay, northeastern Mediterranean. Journal of Applied Ichthyology, 26(3), 441-444. DOI: $10.1111 / \mathrm{j} .1439-0426.2009 .01387 . x$

Gogoi, R. \& Goswami, U.C. (2015). Morphometric and meristic study of Amblypharyngodon mola (HamBuch) from different habitats of Assam. Annals of Biological Research, 6(2), 10-14.

Gurlek, M., Erguden, S., Yaglioglu, D., Turan, F., Demirhan, S., Gungor, M., Ozbalcilar, B. \& Ozcan, T. (2010). Feeding habits of indo-pacific species Nemipterus randalli Russel, 1986 (Nemipteridae) in Iskenderun bay, Eastern 
Mediterranean Sea. Rapports et Procès-Verbaux des Réunions Commission Internationale pour l'Exploration Scientifique de la Mer Méditerranée, 39, 539.

Innal, D., Aksu, M., Akdoganbulut, D., Kisin, B., Unal, M.C., Oztop, M., Dogangil, B. \& Pek, E. (2015). Age and growth of Nemipterus randalli from Antalya Gulf-Turkey. International Journal of Fisheries and Aquatic Studies, 2(4), 299-303.

Kováč, V., Copp, G.H. \& Francis, M.P. (1999). Morphometry of the stone loach, Barbatula barbatula: do mensural characters reflect the species' life history thresholds? Environmental Biology of Fishes, 56(1-2), 105-115. DOI: 10.1007/978-94-017-3678-7_8

Özvarol, Y. (2014). Length-weight relationships of 14 fish species from the Gulf of Antalya (northeastern Mediterranean Sea, Turkey). Turkish Journal of Zoology, 38(3), 342-346. DOI: 10.3906/zoo1308-44

Qadri, S., Shah, T.H., Balkhi, M.H., Bhat, B.A., Bhat, F.A., Najar, A.M., Oyas, A.A., Iram, F. \& Alia, S. (2017). Morphometrics and length-weight relationship of Schizothorax curvifrons Heckel 1838 in River Jhelum, Kashmir, India. Indian Journal of Animal Research, 51(3), 453-458.

Russell, B.C. (1990). Nemipterid Fishes of the World (threadfin breams. whiptail breams. monocle breams. dwarf monocle breams. and coral breams) Family Nemipteridae. An Annotated and Illustrated Catalogue of Nemipterid Species Known to Date. FAO Fisheries Synopsis no. 125. 12. FAO, Rome

Šantić, M., Rađa, B., Paladin, A. \& Čurić, A. (2011). Biometric properties of the European hake, Merluccius merluccius (Osteichthyes: Merlucciidae), from the central Adriatic Sea. Archives of Biological Sciences, 63(1), 259-267. DOI: 10.2298/ABS1101259S

Turan, C. (1999). A note on the examination of morphometric differentiation among fish populations: the truss system. Turkish Journal of Zoology, 23(3), 259-264.

Uyan, U., Filiz, H., Tarkan, A.S., Çelik, M. \& Top, N. (2019). Age and growth of Nemipterus randalli in the southern Aegean Sea, Turkey. Journal of The Black Sea/Mediterranean Environment, 25(2), 140-149.

Uyan, U., Jawad, L.A., Filiz, H., Tarkan, A.S. \& Çelik, M. (2019). Fish length and otolith size of in Nemipterus randalli Russel, 1986 (Actinopterygii: Perciformes: Nemipteridae) collected from Gökova Bay, Turkey. Thalassia Salentina, 41, 137-146. DOI: 10.1285/i15910725v41p137 